\title{
Fungal and seed treatment interference in the viability of coriander seeds
}

\author{
Gizele Ingrid Gadotti ${ }^{1} \mathbb{D}$; Raimunda Nonata $O$ da Silva ${ }^{1} \mathbb{D}$; Cândida Renata J de Farias ${ }^{1} \mathbb{D}$; Joseano G da \\ Silva ${ }^{1} \mathbb{D}$; Henrique L Padão ${ }^{1 \mathbb{D}}$
}

${ }^{1}$ Universidade Federal de Pelotas (UFPel), Pelotas-RS, Brasil; gizeleingrid@gmail.com; nonas_agro@hotmail.com; jacobsencandida@ gmail.com; joseano_agronomo@outlook.com; henriquelpadao@gmail.com

\begin{abstract}
The determination of the sanitary quality is important to diagnose if the commercialized lots are free of pathogens and to make a decision about the need for seed treatment. The objective was to evaluate the interference of fungi associated with coriander seed lots in their physiological performance and the effect of seed treatment with the fungicide Metalaxyl-m + Fludioxonil. The study was carried out in two steps. In experiment I, the physiological potential and sanitary characterization of 18 coriander seed lots were evaluated, using the tests, water content, tetrazolium test and health test. In experiment II, we evaluated the physiological performance of coriander seeds with and without fungicide treatment using the first count and germination test. Coriander seed lots showed high physiological potential, however, not all lots expressed their maximum potential in the germination test without treatment, due to the negative effect of fungi associated with seeds, mainly $A$. dauci and in association with A. alternata. There was an improvement in the physiological performance of coriander seeds treated with Metalaxyl-m + Fludioxonil fungicide.
\end{abstract}

Keywords: Coriandrum sativum, germination, seed health, fungicide.

\section{RESUMO}

Interferência de fungos e do tratamento de sementes na viabilidade de sementes de coentro

A determinação da qualidade sanitária é importante para diagnosticar se os lotes comercializados se apresentam livres de patógenos e para tomada de decisão sobre a necessidade de tratamento de sementes. Objetivou-se avaliar a interferência dos fungos associados às sementes de lotes de coentro e o efeito do tratamento de sementes com o fungicida Metalaxil-m + Fludioxonil. $\mathrm{O}$ estudo foi realizado em duas etapas. No experimento I realizouse a caracterização inicial de 18 lotes de sementes de coentro, por meio dos testes, teor de água, viabilidade e análise sanitária. No experimento II, avaliou-se o desempenho fisiológico de sementes de coentro com e sem tratamento com fungicida por meio do teste de primeira contagem e germinação. Lotes de sementes de coentro que apresentam alto potencial fisiológico podem não expressar seu máximo potencial no teste de germinação sem tratamento com fungicida, pelo efeito negativo causado pelos fungos associados às sementes, principalmente Alternaria dauci e também em associação com A. alternata. Houve melhoria na expressão do desempenho fisiológico de sementes de coentro quando tratadas com o fungicida Metalaxil-m + Fludioxonil.

Palavras-chave: Coriandrum sativum, germinação, sanidade, fungicida.

\section{Received on January 26, 2021; accepted on August 17, 2021}

$\mathrm{C}$ oriander (Coriandrum sativum) belongs to the Apiaceae family. The species originates from the European and African continents. Known as an aromatic, medicinal, and seasoning plant, it is a good source of calcium, iron, vitamin $\mathrm{C}$ and provitamin $\mathrm{A}$. It produces aromatic leaves and fruits, and is a condiment widely used in gastronomy, especially in regions of northeastern Brazil, where fresh stems are consumed (Nascimento et al., 2014).

The production of seeds with high genetic, physiological, physical, and health quality is one of the main challenges faced by seed producers (Bisognin et al., 2016). These attributes characterize a seed lot.

Physiological traits are among the most studied in research. They are related to the metabolism of seeds to fulfill their potential, and can be represented by vigor and germination (Peske et al., 2019). In addition to the physiological quality, determining sanitary quality is very important to diagnose if the lots to be sold are free of pathogens, assisting producers in making decisions about the need for seed treatment.

Among the microorganisms that affect seed quality, fungi stand out as the main group of pathogens associated with seeds, both for their harmful effects and in number of species. These pathogens, when associated with seeds, can cause deterioration, reduced germination and vigor, and death of both the seeds and the developing plant, reducing the crop yield in the field (Lucca-Filho \& Farias, 2019).

The literature points out that fungi 
of the genus Alternaria spp. are one of the main pathogens associated and transmitted via seeds in species of the Apiaceae family, to which coriander, carrots and parsley belong. These cultures are considered of great prominence in the vegetable market in Brazil (Reis et al., 2006; Pedroso et al., 2013, 2018; Töfoli et al., 2015; Barroso et al., 2019). Among the main disease-causing agents in the Apiaceae family, Alternaria dauci, A. alternata, $A$. radicina, and Alternaria sp. should be highlighted. In general, these pathogens can attack different parts of the seedlings, causing leaf stains, lesions on petioles, inflorescences, damage to the roots and seedling damping off, causing largescale losses (Töfoli et al., 2015).

Seeds play a fundamental role in the survival of pathogens during storage, as well as in the transport and transmission of diseases. Thus, it is necessary to adopt measures that reduce the incidence and severity of pathogens (Lucca-Filho \& Farias, 2019).

The chemical treatment of seeds is a promising alternative for the elimination of pathogens associated with seeds, due to the effectiveness of the method, simplicity of application, and reduction of the number of complementary applications while crops are developing (Nascimento et al., 2014).

Seed treatment consists of the application of substances that preserve or improve seed performance, allowing the cultures to express its full genetic potential. This practice aims to protect against the attack of pathogens that may be associated with seeds or be present in the soil (Mentem \& Moraes, 2010).

As stated previously, coriander culture is recurrently affected by fungi that can cause a reduction in seed quality (Trigo et al., 1997; Reis et al., 2006; Pedroso et al., 2013). However, there are no fungicides registered in the Brazilian Ministry of Agriculture for the treatment of coriander seeds (Reis \& Lopes, 2016). Considering this, and the importance of the cultivation of coriander in the national scenario, the development of more in-depth studies is justified, with the aim of establishing a relationship between the rate of fungi incidence, as well as associations of pathogens, and their effect on the physiological performance of commercial coriander seeds lots. Also, as a way to contribute to the improvement of the seed's quality made available on the market and subsidizing the production chain and regulatory bodies, it becomes of fundamental importance. This study sought to analyze the efficiency of a fungicide composed of two chemical groups with different action mechanisms in the control of the main pathogenic fungi that affect the coriander culture.

In view of the above, the objective was to evaluate the interference of fungi associated with coriander seed lots in their physiological performance and the effect of seed treatment with the fungicide Metalaxyl-m + Fludioxonil.

\section{MATERIAL AND METHODS}

The present study was carried out at the Teaching Laboratory for Seed Analysis "Flávio Dias da Rocha," and at the Eliseu Maciel Seed Pathology Laboratory of the School of Agronomy of the Federal University of Pelotas, in 2018. Eighteen commercial coriander seed lots were used, cultivar Verdão, from the southern region of the state of Rio Grande do Sul. While the study was carried out, the seeds remained stored in a cold chamber $\left(17 \pm 1^{\circ} \mathrm{C}\right.$ and $\left.60 \% \mathrm{RH}\right)$.

The study was carried out in two sequential stages. Firstly, the viability and health characterization of coriander seeds were assessed (Experiment I). Subsequently, the physiological performance of coriander seeds with and without fungicide treatment was assessed (Experiment II).

Experiment I was carried out in a completely randomized design, with 18 treatments (lots). In Experiment II, a completely randomized design was used in an $18 \times 2$ factorial arrangement (18 lots and two fungicide treatments), with four replications. The same lots were used in both experiments.

\section{Experiment I - The viability and health characterization of coriander seeds}

The seeds were subjected to the following tests: water content, viability by the tetrazolium test, and health test.

The water content (WC) was analyzed using the oven method at $105 \pm 3^{\circ} \mathrm{C}$ for 24 hours, with two repetitions per lot, according to the Rules for Seed Testing (RST). The results were expressed as an average percentage of water content for each lot (Brasil, 2009a).

The tetrazolium test (TZ) was performed using 100 seeds per repetition. The seeds were preconditioned between paper sheets for 16 hours at $20^{\circ} \mathrm{C}$ (Silva et al., 2021). After the necessary preconditioning time, the seeds were cut longitudinally, and this was carried out keeping half of the two seeds present in the fruit. Then, the seeds were completely submerged in a $0.5 \%$ tetrazolium salt solution for five hours, in the dark, at $40^{\circ} \mathrm{C}$. After the staining period, the seeds were assessed, considering color and integrity of the tissues, classifying them as viable or non-viable.

The fungi in coriander seeds were detected using the "Blotter Test" method. 200 seeds were used, divided into subsamples of 25 seeds, which were sown in "gerbox" plastic boxes, previously sterilized with $70 \%$ alcohol and $1 \%$ sodium hypochlorite, and containing two sterilized blotting paper sheets, moistened with water-restriction solution (06 MPa, $3.1 \mathrm{~g}$ of $\mathrm{NaCl}, 4.0$ $\mathrm{g} \mathrm{KCl}$, and $33.5 \mathrm{~g}$ sucrose). After sowing, the seeds were incubated at $25^{\circ} \mathrm{C}$, with alternating photoperiod (12 $\mathrm{h}$ light and $12 \mathrm{~h}$ dark), for seven days, with adaptations according to Brasil (2009b). After the incubation period, the seeds were analyzed with the aid of a stereoscope and optical microscope to observe the morphological structures of the fungi, with the aid of specialized bibliography (Massola-Júnior et al., 2005; Simmons, 2007; Brasil, 2009b), determining the rate of fungi-infested seeds. For fungi of the genus Alternaria spp., the identifications were made based on morphological characteristics of the conidia visualized in semipermanent slides, and with the aid of specialized bibliography (Simmons, 2007; Brasil, 2009b).

\section{Experiment II - Physiological performance of coriander seeds that received chemical treatment with fungicide}

The seeds were submitted to the first count germination test, and germination 
test with and without chemical treatment with fungicide.

The First Germination Count (FGC) was carried out together with the germination test, on the seventh day after sowing on paper (Brasil, 2009a). The results were expressed as the rate of normal seedlings.

The germination test (GT) was carried out using 100 seeds per repetition. The seeds were sown on blotting paper sheets, moistened with distilled water equivalent to 2.5 times the weight of dry paper. Soon after, the samples were transferred to a germination room with a constant temperature of $20^{\circ} \mathrm{C}$. The evaluation took place 21 days after sowing, considering the rate of normal seedlings, according to the RST (Brasil, 2009a).

For seeds that received chemical treatment with fungicide, the procedure performed in the germination test was the same as described previously. However, the seeds were treated with the fungicide with the active ingredients Metalaxyl-m + Fludioxonil, using 200 $\mathrm{mL} 100 \mathrm{~kg}^{-1}$ of seeds. The mixture volume used was $1.5 \mathrm{~L} 100 \mathrm{~kg}^{-1}$ of seeds, which was composed of the active ingredient and distilled water. The mixture was applied directly to the bottom of a plastic bag and spread to a height of approximately $15 \mathrm{~cm}$, and then the seeds were placed inside the plastic bag, shaking them for three minutes. After the treatment, the plastic bags were opened to allow the seeds to dry at room temperature, according to the methodology adapted from Nunes (2005), and subsequently submitted to the germination test. As the used product is not registered for the coriander culture, the dose was selected based on the generic recommendation for fungi of the genus Alternaria spp., indicated on the product label.

The data were submitted to analysis of variance $(\mathrm{p}<0.05)$ and, when significant, the means were compared using Scott-Knott's test at $5 \%$ probability. The statistical analysis was performed with the Sisvar software, version 5.3.

\section{RESULTS AND DISCUSSION}

Experiment I - Viability and health characterization of coriander seeds

The values for the average water content of coriander seeds ranged from 7.3 to $10.5 \%$ (Table 1). Water content is the most significant factor in preventing seed deterioration during storage. The low water content of the seeds provides a reduction in metabolic activity, which is a contributing factor for the maintenance of their quality (Cardoso et al., 2012).

Analyzing the viability averages determined by the tetrazolium test (Table 1), there was a significant difference between the lots. Lots $3,11,12,14,16$, 17 and 18 showed superior behavior compared to the others, with viability averages above $93 \%$. In general, all lots had high potential for viability, with values ranging from 88 to $97 \%$ among the lots, with a general average of $92 \%$. The tetrazolium test is a biochemical test that can provide a quick estimate of the physiological potential of seeds, that is, those seeds that have the potential to produce a normal seedling (AOSA/ SCST, 2010). However, it should be noted that this test is performed in a shorter time span. This test does not include seed germination, which mitigates the action of possible adverse factors, such as microorganisms that are harmful to seedlings, thus not allowing these factors to interfere in the evaluation and results (Clemente $e t$ al., 2011).

Figure 1 shows the images of the fungi identified in the coriander seeds during the health analysis. In the health analysis of 18 commercial coriander seed lots, several genera of fungi were identified. They were grouped into fungi that are potentially pathogenic for coriander culture, those considered to be storage fungi, and contaminants (Table 2). In this study, greater emphasis was given to fungi considered to have pathogenic potential for the crop (Alternaria dauci and A. alternata). The fungi Cladosporium sp. and Rhizopus sp. were detected in low percentages and because they are considered contaminants were not addressed.

Incidence of $A$. dauci was detected in 17 of the lots under assessment (Table
2), of these on lot 13, the presence of this fungus was not detected. Of the analyzed lots, $1,3,5,16$, and 17 presented rates above $50 \%$. Of these, lots 1,3 , and 17 had an incidence of 84, 91 and $80 \%$, respectively, values well above those found in the literature for this fungus in coriander culture (Reis et al., 2006; Pedroso et al., 2013). Lots 4, 7, 8, 9, 10,11 and 12 had rates lower than $10 \%$ incidence of $A$. dauci. This pathogen is the causal agent of leaf spots or Alternaria leaf spot, considered one of the main diseases that affect coriander, carrots, and parsley cultures (Reis \& Lopes, 2016). The main symptom of this disease is the appearance of brown lesions in the tissues under attack, which, under favorable conditions, evolve, and when about $40 \%$ of the leaf area is affected, the whole leaf turns yellow and dies, causing the typical spots. In addition to the above, another

Table 1. Water content and seed viability of 18 coriander seed lots. Pelotas, UFPel, 2020.

\begin{tabular}{|c|c|c|}
\hline Lots & $\begin{array}{c}\text { Water content } \\
(\%)\end{array}$ & $\begin{array}{c}\text { Viability } \\
(\%)\end{array}$ \\
\hline 1 & 9.8 & $92 \mathrm{~b}$ \\
\hline 2 & 10.5 & $92 \mathrm{~b}$ \\
\hline 3 & 9.4 & $93 \mathrm{a}$ \\
\hline 4 & 9.1 & $91 \mathrm{~b}$ \\
\hline 5 & 10.1 & $90 \mathrm{~b}$ \\
\hline 6 & 9.7 & $92 \mathrm{~b}$ \\
\hline 7 & 9.8 & $92 \mathrm{~b}$ \\
\hline 8 & 9.9 & $90 \mathrm{~b}$ \\
\hline 9 & 9.1 & $88 \mathrm{~b}$ \\
\hline 10 & 9.6 & $90 \mathrm{~b}$ \\
\hline 11 & 9.7 & $94 \mathrm{a}$ \\
\hline 12 & 9.8 & $93 \mathrm{a}$ \\
\hline 13 & 9.7 & $92 \mathrm{~b}$ \\
\hline 14 & 7.3 & $94 \mathrm{a}$ \\
\hline 15 & 8.6 & $90 \mathrm{~b}$ \\
\hline 16 & 9.4 & $97 \mathrm{a}$ \\
\hline 17 & 8.1 & $95 \mathrm{a}$ \\
\hline 18 & 7.6 & $95 \mathrm{a}$ \\
\hline Mean & 9.2 & 92 \\
\hline $\mathrm{CV}(\%)$ & - & 3.06 \\
\hline
\end{tabular}

*Means followed by the same letter in the column do not differ by the Scott-Knott test at $5 \%$ probability; $\mathrm{CV}(\%)=$ coefficient of variation. 
consequence of the attack of this fungus is pre- or post-emergence damping off (Massola-Júnior et al., 2005).

As for the prevalence of A. alternata, the presence of this fungus was found in the 18 lots analyzed; of these, twelve had an incidence above $80 \%$ (Table 2). It was also found that a total of 17 of the 18 evaluated lots presented an association between A. dauci and A. alternata (Table 2). These data reinforce that coriander seeds are important vehicles for the spread of fungi of the genus Alternaria, as previously reported by other authors (Trigo et al., 1997; Reis et al., 2006). In a study by Reis et al. (2006), the authors observed the incidence of these two pathogens in several commercial lots. However, the incidence rate found for both pathogens was well below the rates found in the present study.

Table 2 also shows the incidence of fungi of the genus Aspergillus spp. and Penicillium sp., considered to be storage fungi. However, low rates, ranging from 1 to $10 \%$, were observed for both fungi. The low incidence of these fungi may be related to the favorable storage conditions of the seeds during the analysis period. In this study, the seeds remained stored in a cold chamber with $17 \pm 1{ }^{\circ} \mathrm{C}$ and $60 \% \mathrm{RH}$, while the study was carried out, with a low degree of humidity (Table 1). These conditions are considered unfavorable to the development of storage fungi.

\section{Experiment II - Physiological performance of coriander seeds that received chemical treatment with fungicide}

There was interaction between the lots and chemical treatment with fungicide (Tables 3) for all variables under study. Analyzing the lot effect within each treatment for the variable first germination count (FGC), there was a difference in the quality of the lots (Table 3). Regarding seeds that did not receive fungicide treatment, lots $1,3,5,6,14,15,16$ and 17 showed lower rates of normal seedlings in the first germination count, with averages

Table 2. Incidence and prevalence of fungi in 18 coriander seed lots (\%). Pelotas, UFPel, 2020.

\begin{tabular}{lcccc}
\hline Lots & $\begin{array}{c}\text { Alternaria } \\
\text { dauci }\end{array}$ & $\begin{array}{c}\text { Alternaria } \\
\text { alternata }\end{array}$ & $\begin{array}{c}\text { Aspergillus } \\
\text { spp. }\end{array}$ & $\begin{array}{c}\text { Penicillium } \\
\text { spp. }\end{array}$ \\
\hline 1 & 84 & 51 & 3 & 3 \\
2 & 45 & 68 & 2 & 6 \\
3 & 91 & 68 & 0 & 0 \\
4 & 2 & 87 & 8 & 8 \\
5 & 69 & 43 & 10 & 10 \\
6 & 14 & 80 & 7 & 5 \\
7 & 2 & 83 & 0 & 1 \\
8 & 8 & 89 & 0 & 2 \\
9 & 4 & 89 & 0 & 0 \\
10 & 8 & 81 & 1 & 1 \\
11 & 4 & 90 & 1 & 1 \\
12 & 1 & 79 & 1 & 1 \\
13 & 0 & 88 & 0 & 0 \\
14 & 16 & 86 & 0 & 1 \\
15 & 42 & 70 & 0 & 0 \\
16 & 57 & 81 & 0 & 0 \\
17 & 80 & 82 & 2 & 2 \\
18 & 18 & 96 & 0 & 0 \\
\hline Means & 30 & 78 & 2 & 2 \\
Prevalence & 17 & 18 & 9 & 12 \\
\hline & & & &
\end{tabular}

ranging from 56 to $76 \%$. Lots 4,10 , 11 and 13 had the highest rates, with averages above $90 \%$. The other lots showed an intermediate behavior, with averages ranging from 77 to $84 \%$. For the seeds from lots that received fungicide treatment, lots $1,3,5,6,14$ and 15 also showed the lowest rate of normal seedlings in the FGC, with averages below $80 \%$. The other lots had rates above $80 \%$.

Still for the variable first germination count (Table 3), comparing the effect of each treatment on the performance of the lots, we observed that the lots responded differently to the treatment of seeds with fungicide. Only lots 3, 6, 14, 16 and 17 had significant increases in the rate of normal seedlings in the FGC. For these lots, the use of the fungicide minimized the negative effects of the pathogens associated with the seeds, enabling faster seedling development.

Interaction between the lots and seed treatment with fungicide was also observed for the germination variable (Table 3). Analyzing the lot effect within each according to each treatment, a difference in the quality of the lots was found. For seeds that did not receive fungicide treatment, there was a greater variation in the germination rates between the analyzed lots, which were classified into four quality levels, with averages ranging from 71 to $97 \%$. Lots 1 and 6 had the worst performance in this variable, with averages of 74 and $71 \%$, respectively. These results are consistent with those found in the FGC. However, it is noteworthy that these lots, despite having low germination rates, can be marketed, as their germination rate is above the minimum standard required for the sale of coriander seeds in Brazil, which is $65 \%$ (Brasil, 2019). For seeds treated with fungicide, there was less variation between the averages found in the lots, which were ranked in two levels of quality. The performance of lots 1,5, 7 and 9 was worse than that of the others (Table 3). However, it is noteworthy that all seeds that were chemically treated with fungicide had germination above $80 \%$, and about $77 \%$ of the analyzed lots had germination rates above $90 \%$. These results show that coriander seeds have a high physiological potential, which 


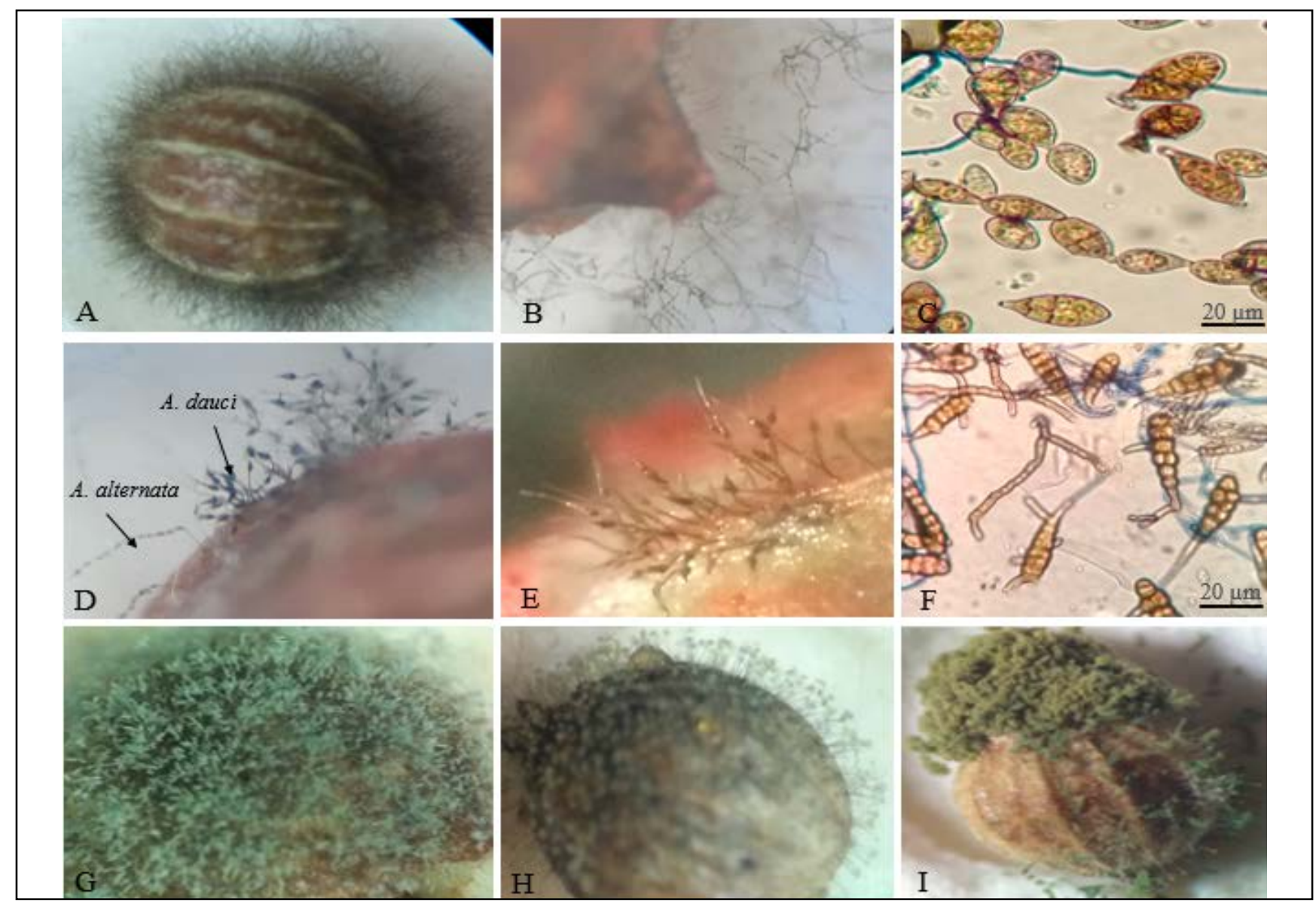

Figure 1. Fungi detected in the sanitary analysis of coriander seeds: $A$. alternata (A and B), conidia of $A$. alternata (C), association between A. alternata and A. dauci present in the same seed (D), A. dauci (E), conidia of A.dauci (F) Pencillium sp. (G), Cladosporium sp. (H) and Aspergillus spp. (I). Pelotas, UFPel, 2020.

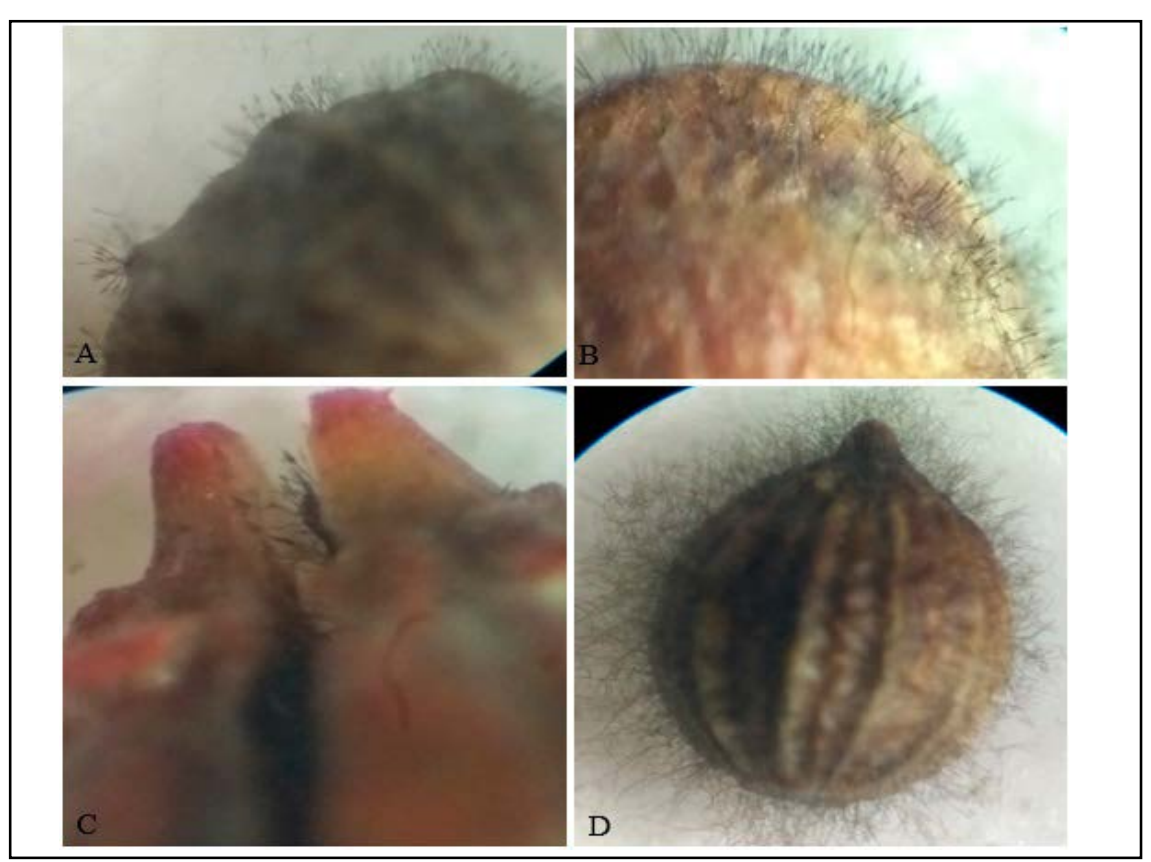

Figure 2. Detail of the association of fungi of the genus Alternaria in coriander seeds: $A$. dauci on the surface of coriander seeds (A and B) and inside the fruit (C) and A. alternata adhered superficially (D). Pelotas, UFPel, 2020. had already been confirmed by data on feasibility found by the tetrazolium test (Table 1, Experiment I). However, the seeds do not always fulfill their maximum potential, mainly because they are infested, predominantly, with fungi with pathogenic potential, as was detected in the health analysis. Thus, seed treatment possibly contributed to an improvement in the physiological performance of these seeds.

Still in Table 3, comparing the results of the germination test according to the fungicide treatment, that the lots behaved differently regarding their response to seed treatment. Despite the increase in germination rate, not all lots had significant responses to seed treatment. But lots 1, 3, 6, 7, 8, 14, 15, 16 and 17 had had a beneficial effect from seed treatment, increasing the germination potential, with increments ranging from 8 to 22 percentage (Table 
3).

The data from the present study revealed different behaviors between lots for the harmful action of pathogenic fungi, physiological performance, and response to treatment with fungicide.

According to the health quality test data, the fungi found in greater proportion were $A$. dauci and $A$. alternata. In this study, the presence of A. dauci was observed both adhered to the surface of the seeds and pedicels, and inside the fruit when it had some kind of opening, as shown in Figures 2A, B and C. The fungus $A$. alternata was only found adhered to the surface of the seeds, without penetrating the fruit (Figure 2D).

To define the appropriate treatment, it is essential to understand the different ways of transmission of the fungi associated with the seeds. Although this study tested only one fungicide, it strategically chose to use a fungicide composed of two chemical groups that have different mechanisms of action, with Fludioxonil providing contact action, while Metalaxyl-m acts systemically. This choice was made aiming at a greater spectrum of action in the control of different pathogens (Syngenta, 2020).

This study was an exploratory research, and more detailed studies of doses and volume of chemical mixture are necessary, since these are decisive factors in the efficiency of the product. During this experiment, there was difficulty in achieving a satisfactory coverage of the surface of the seeds depending on the volume of mixture used, and also the morphological characteristics of the seeds. Another difficulty was due to the small volume of seeds treated in this experiment. Thus, it is still necessary to develop studies that compare not only the efficiency of different fungicides, but also parameters such as dose, mixture volume, among others.

The data obtained in this study demonstrated that all lots had high physiological potential. However, not all lots managed to fulfill their maximum potential in the germination test without treatment, due to the negative effect of fungi on the seeds, mainly $A$. dauci in association with $A$. alternata. However,

Table 3. First germination count and seed germination with and without chemical treatment. Pelotas, UFPel, 2020.

\begin{tabular}{|c|c|c|c|c|c|c|}
\hline \multirow[b]{2}{*}{ Lots } & \multicolumn{3}{|c|}{ First germination count (\%) } & \multicolumn{3}{|c|}{ Germination (\%) } \\
\hline & $\begin{array}{l}\text { Without } \\
\text { treatments }\end{array}$ & Treated $* *$ & Mean & $\begin{array}{l}\text { Without } \\
\text { treatments }\end{array}$ & Treated** & Mean \\
\hline 1 & $68 \mathrm{Da}$ & $68 \mathrm{Ca}$ & 68 & $74 \mathrm{Db}$ & $86 \mathrm{Ba}$ & 80 \\
\hline 2 & $82 \mathrm{Ba}$ & $86 \mathrm{Aa}$ & 84 & $89 \mathrm{Ba}$ & $91 \mathrm{Aa}$ & 90 \\
\hline 3 & $67 \mathrm{Db}$ & $79 \mathrm{Ba}$ & 73 & $82 \mathrm{Cb}$ & $95 \mathrm{Aa}$ & 88 \\
\hline 4 & $90 \mathrm{Aa}$ & $90 \mathrm{Aa}$ & 90 & $95 \mathrm{Aa}$ & $96 \mathrm{Aa}$ & 96 \\
\hline 5 & $74 \mathrm{Ca}$ & $76 \mathrm{Ca}$ & 75 & $79 \mathrm{Ca}$ & $84 \mathrm{Ba}$ & 81 \\
\hline 6 & $56 \mathrm{~Eb}$ & $71 \mathrm{Ca}$ & 64 & $71 \mathrm{Db}$ & $93 \mathrm{Aa}$ & 82 \\
\hline 7 & $80 \mathrm{Ba}$ & $82 \mathrm{Ba}$ & 81 & $81 \mathrm{Cb}$ & $90 \mathrm{Ba}$ & 85 \\
\hline 8 & $77 \mathrm{Ba}$ & $80 \mathrm{Ba}$ & 79 & $85 \mathrm{Cb}$ & $92 \mathrm{Aa}$ & 88 \\
\hline 9 & $83 \mathrm{Ba}$ & $82 \mathrm{Ba}$ & 83 & $86 \mathrm{Ca}$ & $86 \mathrm{Ba}$ & 86 \\
\hline 10 & $92 \mathrm{Aa}$ & $92 \mathrm{Aa}$ & 92 & $97 \mathrm{Aa}$ & $98 \mathrm{Aa}$ & 98 \\
\hline 11 & $94 \mathrm{Aa}$ & $93 \mathrm{Aa}$ & 94 & $97 \mathrm{Aa}$ & $98 \mathrm{Aa}$ & 98 \\
\hline 12 & $84 \mathrm{Ba}$ & $83 \mathrm{Ba}$ & 84 & $91 \mathrm{Ba}$ & $94 \mathrm{Aa}$ & 92 \\
\hline 13 & $91 \mathrm{Aa}$ & $92 \mathrm{Aa}$ & 92 & $96 \mathrm{Aa}$ & $97 \mathrm{Aa}$ & 97 \\
\hline 14 & $69 \mathrm{Db}$ & $79 \mathrm{Ba}$ & 74 & $88 \mathrm{Bb}$ & $96 \mathrm{Aa}$ & 92 \\
\hline 15 & $76 \mathrm{Ca}$ & $75 \mathrm{Ca}$ & 76 & $83 \mathrm{Cb}$ & $93 \mathrm{Aa}$ & 88 \\
\hline 16 & $75 \mathrm{Cb}$ & $88 \mathrm{Aa}$ & 82 & $88 \mathrm{Cb}$ & $97 \mathrm{Aa}$ & 93 \\
\hline 17 & $75 \mathrm{Cb}$ & $91 \mathrm{Aa}$ & 83 & $83 \mathrm{Cb}$ & $97 \mathrm{Aa}$ & 90 \\
\hline 18 & $84 \mathrm{Ba}$ & $88 \mathrm{Aa}$ & 86 & $89 \mathrm{Ba}$ & $95 \mathrm{Aa}$ & 92 \\
\hline Means & 79 & 83 & & 86 & 93 & \\
\hline CV $(\%)$ & \multicolumn{2}{|c|}{$6.92 \%$} & & \multicolumn{2}{|c|}{$5.11 \%$} & \\
\hline
\end{tabular}

*Means followed by the same letter, uppercase in the column and lowercase in the row, do not differ by the Scott-Knott test at $5 \%$ probability; $\mathrm{CV}(\%)=$ coefficient of variation; $* *$ coriander seeds treated with Metalaxil-m + Fludioxonil.

upon receiving chemical treatment with Metalaxyl-m + Fludioxonil fungicide, there was an improvement in the physiological performance of coriander seeds.

\section{ACKNOWLEDGEMENTS}

This work was carried out with the support of the Coordination for the Improvement of Higher Education Personnel, Brazil (CAPES), Financing Code 001, National Council for Scientific and Technological Development (CNPq) and the Federal University of Pelotas, Graduate Program in Seed Science and Technology.

\section{REFERENCES}

AOSA/SCST - Association of Official Seed Analysts and Society of Commercial Seed Technologists. 2010. Tetrazolium Testing
Handbook. AOSA. 414p.

BARROSO, FM; MUNIZ, PHPC; PEIXOTO, GHS; MILAN, MD; CARVALHO, DDC. 2019. Incidência e caracterização morfológica de Alternaria alternata em sementes de salsa. Revista de Agricultura Neotropical 6: 36-40.

BISOGNIN, MB; KULCZYNSKI, SM; FERRARI, M; PELEGRIN, AJ; SOUZA, VQ. 2016. Desempenho fisiológico de sementes olerícolas em diferentes tempos de hidrocondicionamento. Revista de Ciências Agrárias 39: 349-359.

BRASIL. Ministério da Agricultura. Instrução Normativa $\mathrm{n}^{\circ} 42$ de 17 de setembro de 2019. Normas para a produção e a comercialização de sementes olericolas, condimentares, medicinais e aromáticas. Diário Oficial da República Federativa do Brasil, Brasília, 19 set. 2019.

BRASIL, Ministério da Agricultura, Pecuária e Abastecimento. 2009a. Regras para análises de semente / Ministério de Agricultura, Pecuária e Abastecimento. Secretaria de Defesa Agropecuária. Brasília: MAPA/ACS, 399p.

BRASIL, Ministério da Agricultura, Pecuária e 
Abastecimento. 2009b. Manual de Análise Sanitária de Sementes / Ministério de Agricultura, Pecuária e Abastecimento. Secretaria de Defesa Agropecuária. Brasília: MAPA/ACS, 200p.

CARDOSO, RB; BINOTTI, FFS; CARDOSO, ED. 2012. Potencial fisiológico de sementes de crambe em função de embalagens e armazenamento. Pesquisa Agropecuária Tropical 42: 272-278.

CLEMENTE, ACS; CARVALHO, MLM; GUIMARÃES, RM; ZEVIANI, WM. 2011. Preparo das sementes de café para avaliação da viabilidade pelo teste de tetrazólio. Revista Brasileira de Sementes 33: 038-044.

LUCCA-FILHO, OA; FARIAS, CRJ. 2019. Patologia de sementes. In: PESKE, ST; VILLELA, FA; MENEGHELlO, GE (eds). Sementes: fundamentos científicos e tecnológicos. $4^{\mathrm{a}}$ ed. Revisada, atualizada e ampliada. Pelotas: Editora Becker \& Peske Ltda., Pelotas. p.259-353.

MASSOLA-JUNIOR, NS; MARTINS, MC; GLORIA, R; JESUS-JÚNIOR, WC. 2005. Doenças da cenoura. In: KIMATI, H; AMORIN, L; BERGAMIN-FILHO, A; CAMARGO, LEA; RESENDE, JAM (ed). Manual de fitopatologia: doenças das plantas cultivadas. 4. ed. São Paulo: Agronômica Ceres. p. 223-229.

MENTEN, JO; MORAES, MHD. 2010. Tratamento de sementes: histórico, tipos, características e benefícios. Informativo
ABRATES 20: 52-53.

NASCIMENTO, WM; SILVA, PP; VILLELA, RP; WANDERLEY-JUNIOR, LJG. 2014. Produção de sementes de coentro. In: NASCIMENTO, WM (ed). Produção de sementes de hortaliças. $1^{\mathrm{a}}$ ed. Brasília: Embrapa Hortaliças, p.147-167.

NUNES, JC. 2005. Tratamento de semente - qualidade e fatores que podem afetar a sua performance em laboratório. Syngenta Proteção de Cultivos Ltda. 16p.

PEDROSO, DC; LEMES, ES; OLIVEIRA, S; TUNES, LVM; JUNGES, E; MUNIZ, MFB. 2018. Tratamento químico e biológico: qualidade fisiológica e sanitária de sementes de cenoura durante o armazenamento. Pesquisa Agropecuária Pernambucana 23: 01-09.

PEDROSO, DC; MUNIZ, MFB; TUNES, LVM; MÜLLER, J; JUNGES, E; SANTOS, RF. 2013. Influência de Alternaria alternata e $A$. dauci na qualidade de sementes de coentro. Revista Brasileira de Ciências Agrárias 8: 563-569.

PESKE, ST; BARROS, ACSA; SCHUCH, LOB. 2019. Produção de sementes. In: PESKE, ST; VILLELA, FA; MENEGHELLO, GE (eds). Sementes: fundamentos cientificos $e$ tecnológicos. $4^{\mathrm{a}}$ ed. Revisada, atualizada e ampliada. Pelotas: Editora Becker \& Peske Ltda, Pelotas, p.104-143.

REIS, A; LOPES, CA. 2016. Doenças do coentro no Brasil. Brasília, DF: Embrapa. 6p. (Embrapa Hortaliças. Circular Técnica, 157).
Available at $<$ https://ainfo.cnptia.embrapa.br/ digital/bitstream/item/157359/1/CT-157.pdf $>$ Accessed on May, 2020.

REIS, A; SATELIS, JF; PEREIRA, RS; NASCIMENTO, WM. 2006. Associação de Alternaria dauci e A. alternata com sementes de coentro e eficiência do tratamento químico. Horticultura Brasileira 24: 107-111.

SILVA, RNO; GADOTTI, GI; CARVALHO, IL; CARVALHO, IR; SILVA, JG. 2021. Determination of pre-wetting procedure of coriander seeds for tetrazolium test. Horticultura Brasileira 39: 294-298. Available at $<$ https://doi.org/10.1590/s0102-053620210308>. Accessed October 18, 2021.

SIMMONS, EG. 2007. Alternaria: an identification manual. Netherlands: CBS Fungal Biodiversity Centre. 775p.

SYNGENTA. Syngenta Crop Protection AG. 2020. Fungicida/tratamento de sementes/ Maxim ${ }^{\circledR}$ XL. Available at https://www. syngenta.com.br/product/crop-protection/ fungicidatratamento-de-sementes/maxim-xl

TÖFOLI, JG; DOMINGUES, RJ; FERRARI, JT. 2015. Alternaria spp. em oleráceas: sintomas, etiologia, manejo e fungicidas. Biológico 77: 21-34.

TRIGO, MFOO; TRIGO, LFN; PIEROBOM, CR. 1997. Fungos associados às sementes de coentro (Coriandrum sativum L.) no Rio Grande do Sul. Revista Brasileira de Sementes 19: 213-217. 